\title{
A novel in-cylinder fuel reformation approach to control HCCI engine combustion on-set
}

\begin{abstract}
Homogeneous Charge Compression Ignition (HCCI) engines have the potential to deliver high thermal efficiencies (when compared to spark ignition engines) coupled with ultra-low $N_{x}$ emissions and Particulate Matter (PM) for partialload operating regions. However, the inherent absence of Start of Combustion (SOC) or combustion on-set control has been a major obstacle for implementing this technology into production engines. In the present work, a new in-cylinder reformation strategy to control the on-set of combustion has been incorporated into a HCCI engine fuelled with lean ethanol/air mixtures. The objective of the in-cylinder reformation process is to generate hydrogen enriched gas (which includes other intermediate species) from ethanol reformation, which is then used to control the subsequent HCCI cycle combustion on-set. The experimental engine used for the study is a four-stroke, three cylinder In-Direct Injection (IDI) type compression ignition engine which was converted to single cylinder operation for HCCI combustion. A prototype reformation chamber has been designed and fabricated with direct injection capabilities to examine the proposed in-cylinder reformation process. In order to clarify the effects of reformation products on HCCI combustion on-set, experiments were conducted with constant engine speed, initial charge temperature, and engine coolant temperature. The engine performance was evaluated based on cycle-resolved in-cylinder pressure measurements and regulated engineout emissions. The experimental results demonstrate that the proposed in-cylinder reformation strategy is an effective method for controlling HCCI combustion on-set (SOC) and reduces the regulated engine-out emissions. Furthermore, the experimental results indicate that there is an optimal in-cylinder reformation fuelling percentage which will have a positive impact on regular HCCI combustion at given operating conditions.
\end{abstract}

Key words: in-cylinder fuel reformation, HCCI engine, combustion on-set control, ethanol

\section{Nowatorska metoda kontroli momentu zapłonu w silnikach HCCI z wykorzystaniem reformingu paliwa wewnątrz cylindra}

Silniki o zapłonie samoczynnym zasilane mieszanka jednorodna (HCCI) umożliwiaja osiaganie większych wartości sprawności cieplnej w porównaniu do silników o zapłonie iskrowym z jednoczesna ultraniska emisją tlenków azotu NO oraz czastek stałych (PM) w zakresie średnich obciażeń silnika. Jednak brak wyraźnego poczatku spalania (SOC) lub sterowania chwila samozapłonu stanowia ważna przeszkodę wprowadzenia tej technologii do silników produkcyjnych. $W$ tym artykule omówiono zastosowanie nowej metody sterowania chwila samozapłonu $w$ silniku HCCI napędzanym ubogimi mieszankami etanol/powietrze, która jest oparta na procesie reformingu paliwa wewnatrz cylindra (polegajacym na gazyfikacji $i$ wzbogaceniu w wodór, przyp. red.). Celem tego procesu jest wygenerowanie gazu bogatego w wodór podczas reformingu etanolu, który jest następnie używany do kontroli chwili zapłonu w cyklu HCCI.

Do eksperymentu wykorzystano czterosuwowy, trzycylindrowy silnik o zapłonie samoczynnym z wtryskiem pośrednim, który przekształcono w silnik pracujący na pojedynczym cylindrze ze spalaniem typu HCCI. Prototypowa komorę do reformingu zaprojektowano i zbudowano z możliwościa wtrysku bezpośredniego, w celu przetestowania przebiegu tego procesu wewnatrz cylindra.W celu wyjaśnienia wpływu reformingu na chwile samozapłonu HCCI, eksperymenty przeprowadzono przy statej prędkości obrotowej silnika, stałej początkowej temperaturze dawki paliwa oraz czynnika chłodzacego silnika. Pracę silnika oceniano w oparciu o pomiary ciśnienia wewnątrz cylindra i pomiary emisji zwiazków toksycznych. Wyniki eksperymentu pokazuja, że proponowany reforming wewnątrz cylindra jest efektywna metoda kontroli chwili zapłonu HCCI, zmniejszająca również emisję. Wskazują one również, że istnieje optymalny procent paliwa poddawanego reformingowi wewnątrz cylindra, który pozytywnie wplywa na spalanie w silnikach HCCI w danych warunkach.

Słowa kluczowe: reforming paliwa wewnątrz cylindra, spalanie mieszanki jednorodnej, silnik HCCI, kontrola chwili samozapłonu, etanol

\section{Introduction}

The prevailing mode of operation for premixed charged engines, such as Spark Ignition (SI) engines, is mostly in partial loading, or with the throttle valve partially closed. This results in high specific fuel consumption and higher engine-out emissions. The research community is convinced that the HCCI mode of combustion is the key to improve

\section{Wprowadzenie}

Dominującym sposobem działania silników z wstępnie przygotowaną mieszanką, np. silników o zapłonie iskrowym, jest przede wszystkim ich praca na częściowych obciążeniach lub częściowe przymknięcie przepustnicy. Skutkuje to dużym zużyciem określonego paliwa i większą emisją związków toksycznych na wylocie z silnika. Grupa badaw- 
conventional engine performance at partial loads. Coupling the advantages of the HCCI mode of combustion with an alternative fuel is a solution to attain better efficiency engines which can alleviate the dependency of fossil fuels. The alternative fuel that is of our interest is ethanol since it can be produced domestically. Furthermore, ethanol is an attractive fuel of choice engines due to the potential reduction of $\mathrm{CO} 2$ which occurs during the production of crops used for manufacturing ethanol. Ethanol has a high octane number indicating good antiknock performance, high latent heat of vaporization allowing for a denser fuel-air charge, and excellent lean burn properties [1]. However, there are also disadvantages with ethanol due to its low energy density.

The HCCI engine combines the use of pre-mixed air and fuel, usually associated with SI engines, and self-ignition induced by a high compression ratio usually encountered in $\mathrm{CI}$ engines. There are numerous effects associated with the employment of HCCI combustion process such as increased thermal efficiency, lower cycle temperatures and reduced NOx and PM emissions. While there are advantages in exploiting the HCCI mode of operation, there are also a number of drawbacks which need to be addressed. HCCI combustion lacks a means of combustion on-set and subsequent pressure rise control; both the spark ignition timing (SI engine) and the direct in-cylinder injection timing (CI engine) are absent. Also, the HCCI engine operation is limited to partial-load operation only [2].

HCCI engines and various strategies of HCCI combustion control, which include the use of EGR, preheating of intake air, and steam injection, are discussed in a comprehensive review compiled by Zhao et al. [3]. Christensen et al. [4] showed that HCCI combustion is possible with different types of the fuels; regardless of fuel type used increasing the compression ratio has a strong influence on combustion on-set and assists in decreasing the intake charge temperature. Many other studies have been conducted on HCCI combustion using a variety of different fuels including ethanol, dimethyl ether, gasoline, diesel fuel, n-heptane, propane, Compressed Natural Gas (CNG) etc. Studies into HCCI combustion include a broad range of topics, such as, analyzing the effects of Exhaust Gas Recirculation (EGR) [5], intake charge boosting [6], variable valve timing [7] and various fuel injection strategies [8]. Recently, a number of researchers are exploring effects of internal EGR using negative valve overlap to achieve HCCI combustion with conventional compression ratio and lower intake air preheating $[3,9]$. Experimental investigation into effects of in-cylinder reformation utilizing direct fuel injection coupled with the use of Negative Valve Overlap (NVO) technology in a gasoline fuelled HCCI engine was studied in [10-13]. The study [10] showed that a fraction of the total amount of fuel needed for combustion was injected during the NVO period and underwent fuel reformation (fuel converted to hydrogenenriched gas which includes other intermediate species) in reaction with internal EGR, resulting in an extension of the lean limit of HCCI operation without an increase in NOx emissions. In [11] the authors showed that the combustion cza z Uniwersytetu Windsor z Kanady jest przekonana, że sposób spalania w silnikach HCCI stanowi klucz do polepszenia funkcjonowania silnika pracującego na częściowych obciążeniach. Rozwiązaniem, które pozwoli osiągnąć lepszą sprawność silników jest zastosowanie alternatywnego paliwa do spalania w silnikach HCCI, co może również zmniejszyć zależność od paliw kopalnych. Paliwem alternatywnym będącym przedmiotem naszego zainteresowania jest etanol, który może być wytwarzany w warunkach domowych. Ponadto etanol wydaje się atrakcyjnym paliwem umożliwiającym redukcję $\mathrm{CO}_{2}$ powstającego w czasie upraw zbóż używanych do wytwarzania etanolu. Etanol charakteryzuje się dużą liczbą oktanową świadczącą o dobrym działaniu przeciwstukowym, dużym utajonym ciepłem parowania pozwalającym na zastosowanie gęstszej mieszanki paliwowo-powietrznej oraz doskonałymi właściwościami spalania ubogich mieszanek [1]. Jednak są też pewne mankamenty użycia etanolu, wynikające z jego małej gęstości energii.

Silniki typu HCCI łączą użycie wstępnie ujednorodnionej mieszanki powietrze-paliwo, zwykle kojarzonej z silnikami o zapłonie iskrowym, z samozapłonem wywołanym przez duży stopień sprężania, typowy dla silników o zapłonie samoczynnym. Stosowanie spalania takiego jak w silnikach HCCI ma wiele skutków: zwiększoną sprawność cieplną, niższe temperatury cyklu oraz zredukowanie emisji tlenków azotu $\mathrm{NO}_{\mathrm{x}} \mathrm{i}$ cząsteczek stałych. Chociaż proces spalania w silnikach HCCI ma wiele zalet, to istnieją też wady wymagające zwrócenia szczególnej uwagi. W spalaniu występującym w silnikach HCCI brak jest mechanizmu kontroli rozpoczęcia spalania i następującego wzrostu ciśnienia; brakuje również kontroli chwili zapłonu (jak w silnikach ZI) oraz czasu bezpośredniego wtrysku do cylindra (jak w ZS). Działanie silnika HCCI jest również ograniczone do pracy jedynie na częściowych obciążeniach [2].

Zhao i in. [3] opracowali obszerny przegląd silników HCCI wraz z metodami kontroli spalania w tych silnikach, obejmujący wykorzystanie systemu recyrkulacji spalin (EGR), wstępne ogrzanie pobieranego powietrza oraz wtrysk pary. Christensen i in. [4] pokazali, że spalanie w silnikach HCCI jest możliwe przy zastosowaniu różnych rodzajów paliw; bez względu na użyty rodzaj paliwa zwiększanie stopnia sprężania ma duży wpływ na chwilę zapłonu i pomaga zmniejszyć temperaturę ładunku w cylindrze.

W zakresie procesów spalania w tych silnikach przeprowadzono liczne badania z wykorzystaniem różnych paliw, w tym etanolu, eteru dimetylowego, benzyny, oleju napędowego, n-heptanu, propanu, gazu sprężonego (CNG) itd. Badania nad spalaniem HCCI obejmują wiele zagadnień, takich jak analiza efektów recyrkulacji spalin (EGR) [5], doładowanie do układu dolotowego [6], zmienny czas otwarcia zaworów [7] i różne sposoby wtrysku paliwa [8]. Od niedawna wielu naukowców zajmuje się badaniem efektów wewnętrznej recyrkulacji spalin, wykorzystującej ujemny czas pokrycia faz rozrządu zaworów dolotowych i wylotowych (Negative Valve Overlap - NVO), aby procesy spalania w silnikach HCCI zachodziły przy konwencjonalnym stopniu sprężania i niższej temperaturze zasysanego powietrza $[3,9]$. 
phasing could be controlled by the amount of fuel injected during the NVO pilot fuel injection period. The results from $[12,13]$ discovered that fuel injection during the NVO period can indeed advance the SOC when comparing the process to that of normal HCCI operation. The study [12] showed that there is an optimum amount/portion of fuel required for the reformation process depending on engine operating conditions. While the results from [13] showed that there is an optimal injection timing and fuel percent for each load during the NVO period which results in the lowest emissions and ISFC.

In this study, the use of in-cylinder reformation process to generate hydrogen enriched reformate gas with other intermediate species to control the HCCI SOC is examined. The experimental results demonstrate that the proposed in-cylinder reformation strategy is effective in controlling the HCCI combustion on-set. Furthermore, the proposed methodology also has some unique advantages over the NVO in-cylinder reformation process.

\section{Experimental apparatus}

The experimental setup consists of a four stroke, threecylinder compression-ignition engine (Kubota D905) converted for single cylinder HCCI operation with a port-fuel injector in the intake system. The port-fuel injection system is designed to be compatible for operation with alcohols. The stock engine was an IDI-type CI engine with a pre-chamber. The engine is motored using an AC motor with a variable speed drive (VSD). The VSD system is used to maintain the engine speed at desired Revolutions per Minute (RPM) during both motoring and firing scenarios. The VSD has an additional resistor bank that dissipates the additional power generated by the engine during firing conditions. The experimental set-up also consists of an intake air pre-heater and a laminar flow element in conjunction with a differential pressure transmitter is used to measure the airflow rate into the intake system of the engine. Also, a number of K-Type thermocouples were installed along the intake and exhaust pipes to record the intake and exhaust gas temperatures.

A Kistler piezoelectric $5 \mathrm{~mm}$ wall-mounted transducer (6052A1) is mounted utilizing the glow plug passage to acquire in-cylinder pressure measurements. An optical encoder with a $0.1^{\circ} \mathrm{Crank}$ Angle (CA) resolution was used for engine speed and crank angle measurements. A Combustion Analysis System (CAS) was used for acquiring the pressure and crank angle data. The CAS system has a resolution of $0.1^{\circ} \mathrm{CA}$ for both pressure and encoder measurements at the maximum rated engine speed. The regulated engine-out emissions were evaluated using a portable MicroGasTM 5 -gas analyzer.

\section{In-cylinder reformation}

The in-cylinder or internal reformation strategy in general is similar to the auto-thermal reformation process. However, instead of steam and air, the lean HCCI exhaust gas or combustion product (which is ideally comprised of $\mathrm{O}_{2}, \mathrm{H}_{2} \mathrm{O}, \mathrm{CO}_{2}$ and $\mathrm{N}_{2}$ ) is used for fuel reformation. The use of exhaust gas or combustion products exploits the high temperature associ-
W pracach [10-13] omówiono eksperymentalne badania efektów reformingu wewnątrz cylindra $\mathrm{z}$ wtryskiem bezpośrednim w połączeniu z wykorzystaniem strategii NVO w silniku HCCI zasilanym benzyną. W badaniach przedstawionych w pracy [10] wykazano, że skład wtryśniętej w czasie NVO części dawki paliwa potrzebnej do spalania uległ zmianie (paliwo przekształciło się w gaz o zwiększonej zawartości wodoru) na skutek reakcji z wewnętrznym systemem recyrkulacji spalin, prowadząc do powiększenie obszaru pracy silnika HCCI zasilanego ubogą mieszanką, bez jednoczesnego wzrostu emisji tlenków azotu. W pracy [11] autorzy wykazali, że poszczególne fazy spalania można kontrolować przez ilość paliwa wtryskiwanego w czasie NVO. Wyniki z prac $[12,13]$ pokazują, że wtrysk paliwa w czasie NVO przyspiesza chwilę samozapłonu w porównaniu ze standardowym procesem spalania w silnikach HCCI. Badania przedstawione w publikacji [12] pokazały, że istnieje optymalna dawka paliwa wymagana do procesu reformingu w zależności od warunków pracy silnika. Wyniki przedstawione w [13] pokazały, że istnieje również optymalny czas wtrysku i odpowiednia dawka paliwa dla różnych obciążeń silnika w czasie NVO, które skutkują najmniejszą emisją i najmniejszym zużyciem paliwa.

Ten artykuł przedstawia wykorzystanie procesu reformingu zachodzącego w cylindrze i prowadzącego do uformowania gazu o zwiększonej zawartości wodoru do kontroli chwili samozapłonu w silnikach HCCI. Wyniki eksperymentu pokazują, że proponowana metoda reformingu wewnątrz cylindra umożliwia kontrolę chwili samozapłonu. Ponadto ta metoda ma również wyjątkową przewagę nad procesem reformingu wewnątrz cylindra w czasie NVO.

\section{Aparatura badawcza}

Układ eksperymentalny składa się z czterosuwowego, trzycylindrowego silnika o zapłonie samoczynnym (Kubota D905), przekształconego w silnik HCCI pracujący na pojedynczym cylindrze i z jednopunktowym wtryskiem paliwa w układzie wlotowym. Układ jednopunktowego wtrysku paliwa został przystosowany do spalania alkoholi. Silnik podstawowy był silnikiem o ZS z wtryskiem pośrednim i komorą wstępną. Silnik spalinowy jest napędzany elektrycznym silnikiem asynchronicznym z napędem o zmiennej prędkości obrotowej (Variable Speed Drive - VSD). Systemu VSD używa się do utrzymywania pożądanej prędkości obrotowej silnika podczas jego pracy i spalania. System VSD ma dodatkowy zespół oporników rozpraszających nadmiar mocy generowanej przez silnik w czasie pracy. Układ badawczy zawiera także system podgrzewania pobieranego powietrza. System przepływu laminarnego połączony z czujnikiem ciśnienia różnicowego użyto do pomiaru wskaźnika przepływu powietrza do systemu dolotowego silnika. Poza tym zainstalowano kilka termopar typu K (chromel-alumel) wzdłuż rur wlotowych i wydechowych do rejestrowania temperatur powietrza dolotowego i spalin. Zamontowano też piezoelektryczny przetwornik Kistlera (6052A1) o średnicy $5 \mathrm{~mm}$, wykorzystujący adapter świecy żarowej do pomiarów ciśnienia wewnątrz cylindra. Do mierzenia prędkości obrotowej silnika i kąta położenia wału korbowego użyto dekodera 
ated with them. Higher temperatures which are favorable to the reformation reaction can be achieved by using a proper in-cylinder methodology, such as, negative valve overlap [10-13] or the ne proposed here.

Figure 1 shows the proposed methodology which utilizes a separate reformation chamber built as an integral part of the main combustion chamber. A mechanical valve and a direct fuel injector for reformation fuelling are used to carry out the in-cylinder reformation process. The valve in the reformation chamber is used for isolating the reformation chamber volume from the main combustion chamber during the reformation process.

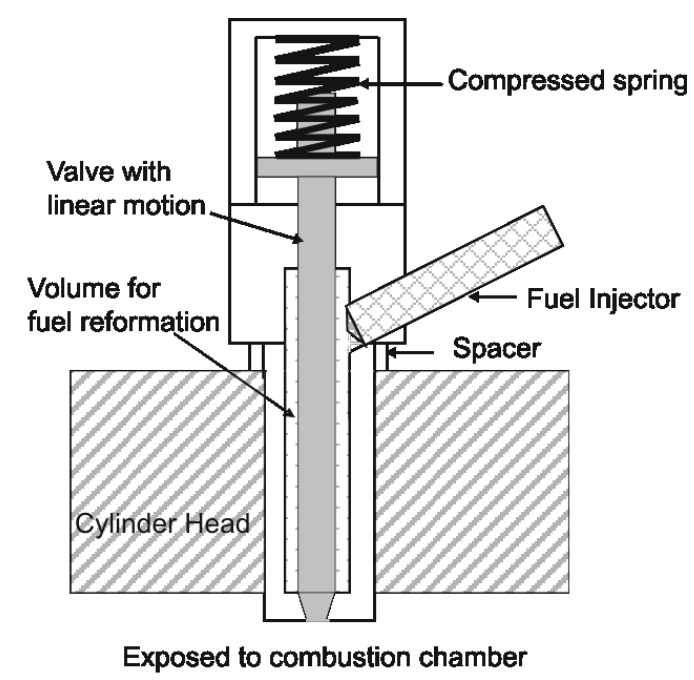

Fig. 1. Proposed in-cylinder reformation concept

Rys. 1. Proponowana koncepcja reformingu wewnatrz cylindra

The first stage in fuel reformation is achieved by trapping a fraction of residual combustion products in the reformation chamber (at $80^{\circ} \mathrm{CA}$ After Top Dead Center (ATDC) during the expansion stroke) before the opening of the exhaust valve, minimizing the temperature loss from the expansion of gases. Then a fraction of the fuel is injected into the reformation chamber which undergoes the reformation process. Mixing of reformation products with fresh charge is accomplished at $15^{\circ} \mathrm{CA} \mathrm{Before} \mathrm{Top} \mathrm{Dead} \mathrm{Center} \mathrm{(BTDC)}$ during the compression stroke of the next cycle. It should be noted that the reformation chamber is kept open from $15^{\circ} \mathrm{CA}$ BTDC (compression stroke) until $80^{\circ} \mathrm{CAATDC}$ (expansion stroke) during which the regular HCCI combustion process takes place (in both main and reformation chamber).

Figure 2 shows the prototype reformation chamber developed to test the above proposed in-cylinder reformation concept. A pencil-type direct fuel injector in conjunction with the stock mechanical fuel pump is used for fuel injection during the reformation process. The direct injector fuel-injection pressure was reduced to match the stock fuel pump (mechanical) injection pressure (125 bar). The valve with linear motion which is utilized to trap the combustion products and to isolate the reformation chamber from the main chamber is also shown in Fig. 2. The valve opens and allows mixing of the reformation products (contained in optycznego z rozdzielczością $0,1^{\circ} \mathrm{OWK}$. System analizy spalania (CAS) wykorzystano do uzyskania danych na temat ciśnienia i kąta położenia wału korbowego. System CAS ma rozdzielczość $0,1^{\circ} \mathrm{OWK}$ zarówno przy pomiarach ciśnienia, jak i dekodera przy maksymalnej rejestrowanej prędkości obrotowej silnika. Emisję silnika zmierzono za pomocą przenośnego analizatora gazu typu MicroGasTM 5.

\section{Reforming wewnątrz cylindra}

Metoda reformingu wewnętrznego lub wewnątrz cylindra jest podobna do procesu reformingu autotermicznego. Jednakże w silnikach HCCI zamiast pary i powietrza do reformingu paliwa używane są spaliny pochodzące ze spalania ubogiej mieszanki jednorodnej, albo produkty spalania (najlepiej, gdyby składały się z $\mathrm{O}_{2}, \mathrm{H}_{2} \mathrm{O}, \mathrm{CO}_{2} \mathrm{i} \mathrm{N}_{2}$ ). Użycie gazu spalinowego lub produktów spalania wymaga wysokiej temperatury. Korzystne dla reakcji reformingu wysokie temperatury mogą być uzyskane dzięki zastosowaniu odpowiedniej technologii wewnątrz cylindra, takiej jak NVO [10-13], lub zaproponowanej w niniejszej pracy.

Proponowaną technologię, wykorzystującą oddzielną komorę reformingu, wbudowaną jako integralna część głównej komory spalania, przedstawia rys. 1 .

Do przeprowadzenia reformingu wewnątrz cylindra używa się bezpośredniego wtrysku paliwa i mechanicznego zaworu, który oddziela objętość, w której odbywa się reforming od głównej komory spalania.

Pierwszy etap reformingu paliwa zachodzi przez uwięzienie części produktów spalania w komorze reformingu (przy kącie $80^{\circ} \mathrm{OWK}$ po GMP podczas suwu spalania) przed otwarciem zaworu wylotowego, co minimalizuje zmniejszenie temperatury w wyniku rozprężania gazów. Następnie część paliwa wtryskuje się do komory reformingu, gdzie przechodzi ono proces reformingu. Przy kącie $15^{\circ} \mathrm{OWK}$ przed GMP następuje zmieszanie produktów reformingu ze świeżym ładunkiem podczas suwu sprężania w następnym cyklu. Należy zauważyć, że komora reformingu pozostaje otwarta między $15^{\circ} \mathrm{OWK}$ przed GMP (sprężanie) a $80^{\circ}$ OWK po GMP (rozprężanie), kiedy to zachodzi proces spalania w silnikach HCCI (w komorach głównej i reformingowej).

Rysunek 2 przedstawia prototypową komorę reformingową opracowaną do przetestowania proponowanej koncepcji reformingu wewnątrz cylindra. Podczas procesu reformingu do wtrysku paliwa używa się bezpośredniego wtryskiwacza połączonego z seryjną mechaniczną pompą paliwa. Ciśnienie wtrysku paliwa we wtryskiwaczu zmniejszono do poziomu ciśnienia wtrysku mechanicznego w seryjnej pompie paliwa (125 barów).

Na rysunku 2 przedstawiono również zawór o charakterystyce liniowej używany do uwięzienia produktów spalania i izolowania komory reformingowej od komory głównej. Zawór, otwierając się, umożliwia zmieszanie produktów reformingu (będących w komorze reformingowej) ze świeżym ładunkiem podczas nowego cyklu przy kącie $15^{\circ} \mathrm{OWK}$ przed GMP (sprężanie). Otwieranie i zamykanie zaworu w proponowanej komorze reformingowej jest kontrolowane przez użycie sprężyny z napięciem wstępnym, która działa 
the reformation chamber) with fresh charge during the next cycle at $15^{\circ} \mathrm{CA}$ BTDC (compression stroke). The opening and closing of the valve in the current reformation chamber design is controlled using a pre-compressed precision compression spring that acts on the valve. Depending on the spring design parameters and the amount by which the spring is pre-compressed, the CA at which the cylinder pressure (acting on the valve) that overcomes the spring force during the compression stroke can be manipulated. An ideal control for the precise opening and closing of the reformation chamber valve is through the use a cam with different lobe profiles depending on the timing desired.

The physical separation of the reformation process from the main engine operating processes (intake, compression, power and exhaust) is essential in effectively controlling the temperature and/or the oxygen content of the trapped residual gases that participate in reformation. In the proposed method, the control over oxygen content and temperature of the trapped residual gas is achieved by manipulating the time at which the residual gases are captured during the expansion stroke. The volumetric efficiency of the engine is not affected since the intake and exhaust valve timings were not manipulated. Furthermore, the main advantage of the proposed method over the NVO strategy is that the products of reformation can be mixed with the fresh charge (next cycle) during the compression stroke rather than at the start of the intake stroke. This control over mixing of reformation products with fresh charge provides us with direct control of the on-set or start of HCCI combustion similar to spark ignition in SI engines or direct injection in CI engines.

The volume of the fabricated reformation chamber to trap the combustion products for reformation is $5 \mathrm{cc}$. This volume corresponds to $3 \%$ of the total combustion chamber volume (main chamber plus the reformation chamber), when the reformation chamber valve is closed at $80^{\circ} \mathrm{CA}$ ATDC during the expansion stroke. It should be noted that the exhaust valve opens at $125^{\circ}$ ATDC during the expansion stroke. Hence, care must be taken such that the reformation chamber valve closes before the exhaust valve opens $\left(125^{\circ}\right.$ CA ATDC) in order to avoid a drop in the temperature of trapped combustion products resulting from expansion of the gases to atmospheric pressure.

The theoretical reformation reaction for ethanol with combustion products from previous cycle with an equivalence ratio of 0.37 is

$$
\begin{aligned}
& \mathrm{C}_{2} \mathrm{H}_{5} \mathrm{OH}+0.0658\left(2 \mathrm{CO}_{2}+3 \mathrm{H}_{2} \mathrm{O}+5.1 \mathrm{O}_{2}+\right. \\
& \left.+30.5 \mathrm{~N}_{2} \rightarrow 2.13 \mathrm{CO}+3.197 \mathrm{H}_{2}+2.007 \mathrm{~N}_{2}\right)
\end{aligned}
$$

The heat of reaction for the above equation 1 based on the enthalpies of products and reactants is $+99.07 \mathrm{MJ} / \mathrm{kmol}$. For the experimental engine operating at an equivalence ratio of 0.37 with reformation valve closing at $80^{\circ} \mathrm{CAATDC}$, the amount of fuel that corresponds to the above theoretical reformation fuel-oxidizer equivalence ratio is $40.5 \%$ of the total fuel injected per cycle (by mass). This amount is based only on the oxygen content in the combustion products. It should na zawór. W zależności od parametrów konstrukcji sprężyny i napięcia wstępnego można zmieniać kąt położenia wału korbowego, w którym ciśnienie cylindra (działające na zawór) przezwycięża siłę sprężyny podczas sprężania. Najlepsza kontrola precyzyjnego otwarcia i zamknięcia zaworu komory reformingowej następuje przez użycie wałka rozrządu o różnych profilach krzywek w zależności od pożądanych faz rozrządu.

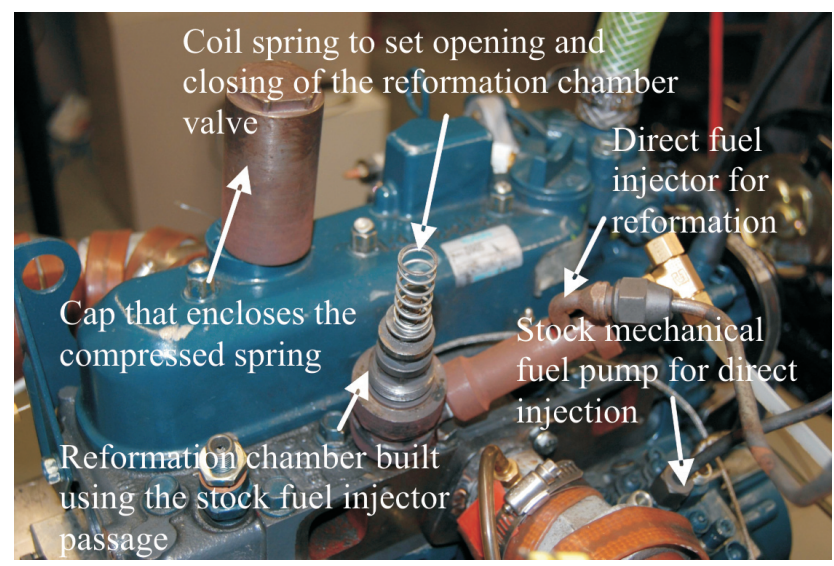

Fig. 2. Implemented prototype reformation chamber on experimental engine

Rys. 2. Zastosowana prototypowa komora reformingowa $w$ silniku eksperymentalnym

Fizyczne oddzielenie procesu reformingu od głównych procesów zachodzących w cylindrze silnika (ssanie, sprężanie, praca, wydech) jest istotne dla efektywnej kontroli temperatury i zawartości tlenu w uwięzionych pozostałościowych gazach biorących udział w reformingu. W proponowanej technologii zmiana czasu wychwytywania pozostałości gazów podczas suwu umożliwia kontrolę zawartości tlenu i temperatury zamkniętych gazów. Współczynnik napełnienia cylindrów silnika nie ulega zmianom, ponieważ nie zmieniano czasu otwarcia zaworów dolotowych i wylotowych. Ponadto główną przewagą proponowanej technologii nad użyciem strategii NVO jest to, że produkty reformingu mogą być mieszane ze świeżym ładunkiem (następny cykl) dopiero podczas suwu sprężania, a nie na początku suwu ssania.

Taka kontrola mieszania produktów reformingu ze świeżym ładunkiem pozwala na bezpośrednią kontrolę chwili samozapłonu w silnikach HCCI podobną do zapłonu iskrowego w silnikach SI lub też wtrysku bezpośredniego w silnikach o ZS.

Objętość zbudowanej komory reformingu wynosi $5 \mathrm{~cm}^{3}$. Ta objętość odpowiada 3-procentowej całkowitej pojemności komory spalania (główna komora plus komora reformingowa), kiedy zawór komory reformingowej jest zamknięty przy kącie $80^{\circ} \mathrm{OWK}$ po GMP podczas suwu pracy. Należy zauważyć, że zawór wylotowy otwiera się $125^{\circ} \mathrm{OWK}$ po GMP podczas suwu rozprężania. Stąd należy dopilnować, aby zawór komory reformingowej zamykał się przed otwarciem zaworu wylotowego, w celu uniknięcia spadku temperatury uwięzionych produktów spalania w wyniku rozprężenia gazów do poziomu ciśnienia atmosferycznego. 
be realized that the temperature of the trapped combustion products also plays a vital role in the reformation process and hence the amount of fuel that is ideal for reformation might be lesser than the $40.5 \%$. Also consider the fact that ethanol has a higher latent heat of vaporization and the amount of fuel injected for fuel reformation will have an impact on the overall temperature of the trapped combustion products. Furthermore, it can be noted any increase in the engine operating equivalence ratio will lead to decrease in the oxygen content of the trapped combustion products. This in turn will lead to decrease in the above indicated fuel percentage that provides the theoretical reformation equivalence ratio. However, trapping the combustion products before $80^{\circ} \mathrm{CA}$ ATDC should increase the amount of combustion products in the reformation chamber and therefore the oxygen content (because of higher cylinder pressure). The temperature of the trapped combustion products will also increase with both early closing of the reformation valve and increase in equivalence ratio. Hence, the $\mathrm{CA}$ at which the reformation valve closes during the expansion stroke is important in dictating the favorable temperature of the trapped combustion products and the amount of fuel used for reformation. Other experimental studies $[12,13]$ confirm that the temperature and the oxygen content of the trapped combustion products plays an important role in attaining higher hydrogen yield during the reformation process.

\section{Test condition}

The engine parameters and operating conditions used in the study are as follows: compression ratio, $\mathrm{r}_{\mathrm{v}}=16: 1$, cylinder bore diameter, $\mathrm{D}=72 \mathrm{~mm}$, cylinder stroke, $\mathrm{S}=73.6 \mathrm{~mm}$, engine coolant temperature, $\mathrm{T}_{\mathrm{c}}=75^{\circ} \mathrm{C}\left( \pm 1^{\circ} \mathrm{C}\right)$ and intake charge temperature, $\mathrm{Ti}=150^{\circ} \mathrm{C}\left( \pm 2^{\circ} \mathrm{C}\right)$. The reformation chamber valve is closed at $80^{\circ} \mathrm{CAATDC}$ (expansion stroke) and the fuel for reformation is injected at $95^{\circ} \mathrm{CAATDC}$ (expansion stroke). The reformation chamber valve is opened at $15^{\circ} \mathrm{CA}$ BTDC (compression stroke). The amount of fuel injected in to the reformation chamber varies between $0-25 \%$ (by mass) of the total fuel used per cycle.

\section{Results and discussion}

Figure 3 shows the in-cylinder pressure and the pressurerise rates for the engine motoring condition with various reformation chamber opening and closing conditions.

The two solid lines (arked as (a) and (b) in Fig. 3) represent the pressure traces when the reformation chamber is kept open (a) or closed (b) throughout the entire cycle. The difference in their peak pressure is due to difference in the clearance volumes between cases (a) and (b). The clearance volume is decreased by $25 \%$ for the case (b) resulting in an increased overall compression ratio of the engine. The mechanical compression ratio of the engine with reformation chamber kept closed throughout the compression stroke is 21:1. The dotted line in Fig. 3 represents the pressure trace when the reformation chamber is opened at $15^{\circ} \mathrm{BTDC}$ and closed at $80^{\circ} \mathrm{CA}$ ATDC (current configuration). It should be noted that clearance volume at TDC for this motoring condition (dotted line) is equal to the case (a) (motoring condition
Teoretyczną reakcję reformingu dla etanolu z produktami spalania z poprzedniego cyklu ze współczynnikiem równoważności 0,37 (stosunek masy paliwa do masy powietrza, przyp. tłum.) przedstawia wzór (1).

Ciepło reakcji dla równania (1) wyznaczone w oparciu o entalpię produktów i reagentów wynosi $+99,07$ $\mathrm{MJ} / \mathrm{kmol}$. Dla silnika eksperymentalnego działającego przy współczynniku równoważności 0,37 i zamknięciu zaworu reformingowego przy kącie $80^{\circ} \mathrm{OWK}$ po GMP, ilość paliwa, która odpowiada powyższemu teoretycznemu reformingowemu współczynnikowi równoważności paliwo-utleniacz, to $40,5 \%$ sumy paliwa wtryskiwanego na cykl (masowo). Ta ilość jest oparta wyłącznie na zawartości tlenu w produktach spalania. Należy pamiętać, iż temperatura uwięzionych produktów spalania także odgrywa znaczną rolę w procesie reformingu, stąd też ilość paliwa, idealna dla tego procesu, mogłaby być mniejsza niż 40,5\%. Poza tym należy uwzględnić fakt, że etanol ma wyższe utajone ciepło parowania i ilość paliwa wtryskiwanego do reformingu będzie miała wpływ na ogólną temperaturę uwięzionych produktów spalania. Ponadto można zauważyć, że jakikolwiek wzrost współczynnika równoważności pracy silnika doprowadzi do obniżenia zawartości tlenu w uwięzionych produktach spalania. To z kolei obniży wyżej podany udział procentowy paliwa, który pozwala obliczyć teoretyczny współczynnik równoważności reformingu. Jednak uwięzienie produktów spalania poniżej kąta $80^{\circ} \mathrm{OWK}$ po GMP powinno zwiększyć ilość produktów spalania w komorze reformingowej i tym samym zawartość tlenu (z powodu wyższego ciśnienia w cylindrze). Temperatura uwięzionych produktów spalania wzrośnie również wraz z wczesnym zamknięciem zaworu reformingowego i wzrostem współczynnika równoważności.

Zatem wartość kąta OWK, przy którym zawór reformingowy zamyka się podczas suwu pracy jest ważny przy ustaleniu korzystnej temperatury uwięzionych produktów spalania i ilości paliwa użytego do reformingu.

Inne badania eksperymentalne $[12,13]$ potwierdzają, że temperatura i zawartość tlenu uwięzionych produktów spalania odgrywają znaczącą rolę w osiąganiu większej zawartości wodoru podczas procesu reformingu.

\section{Warunki badania}

Parametry silnika i warunki badań są następujące: stopień sprężania $\mathrm{r}_{\mathrm{v}}=16$, średnica cylindra $\mathrm{D}=72 \mathrm{~mm}$, skok tłoka $\mathrm{S}=73,6 \mathrm{~mm}$, temperatura chłodziwa silnika $\mathrm{T}_{\mathrm{c}}=75^{\circ} \mathrm{C}$ $\left( \pm 1^{\circ} \mathrm{C}\right)$ i temperatura ładunku $\mathrm{T}_{\mathrm{i}}=150^{\circ} \mathrm{C}\left( \pm 2^{\circ} \mathrm{C}\right)$. Zawór komory reformingowej jest zamknięty przy kącie $80^{\circ} \mathrm{OWK}$ po GMP (suw rozprężenia), a paliwo do reformingu jest wtryskiwane przy kącie $95^{\circ} \mathrm{OWK}$ po GMP (suw sprężania). Zawór komory reformingowej jest otwarty przy kącie $15^{\circ}$ OWK przed GMP (suw sprężania). Ilość paliwa wtryskiwanego do komory reformingowej waha się w zakresie 0-25\% (masowo) ilości paliwa użytego w cyklu.

\section{Wyniki i dyskusja}

Rysunek 3 przedstawia ciśnienie wewnątrz cylindra i szybkość wzrostu ciśnienia dla warunków pracy silnika przy różnych warunkach otwierania i zamykania komory reformingowej. 


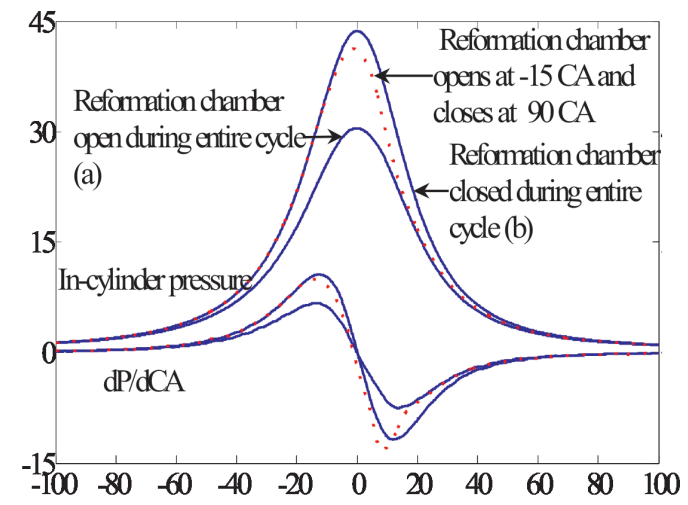

Fig. 3. In-cylinder pressure and pressure-rise rate $(\mathrm{dP} / \mathrm{dCA})$ for various motoring conditions $\left(\mathrm{T}_{\text {in }}=150^{\circ} \mathrm{C}\right.$ and $\left.\mathrm{T}_{\mathrm{c}}=75^{\circ} \mathrm{C}\right)$

Rys. 3. Ciśnienie wewnątrz cylindra i szybkość wzrostu ciśnienia (dP/dCA) dla różnych warunków pracy $\left(150^{\circ} \mathrm{C} i T_{c}=75^{\circ} \mathrm{C}\right)$

with 30 bar peak pressure). However, manipulation of the reformation chamber opening time during the compression stroke results in temporarily varying the compression ratio of the engine during the intermediate period of the compression stroke. The intermediate change in the compression ratio results in a higher peak pressure and temperature at the end of the compression stroke (TDC) than the solid line (a). This can be viewed from Fig. 3 where the dotted line at first follows the pressure curve with the chamber closed (solid line b) until $15^{\circ} \mathrm{CA}$ BTDC and then shifts down to the pressure curve that represents chamber open condition (solid line a) after $10^{\circ} \mathrm{CA}$ ATDC. This results in attaining a higher TDC pressure and temperature than the regular engine compression, an inherent advantage of the proposed reformation methodology. Simply by varying the reformation chamber opening time during the compression stroke, the SOC $(10 \% \mathrm{HR})$ can be altered for a particular intake charge and coolant temperature. This is further confirmed from our experimental results where combustion was witnessed only when the valve is opened after $15^{\circ} \mathrm{CA}$ BTDC for all the operating conditions discussed below.

Figures 4 through 9 show the in-cylinder pressure and HRR for various engine operating conditions. In all the figures, the solid line represents the no reformation fuelling case and the dotted line represents when a percentage fuel is injected for reformation. The intake charge temperature $\left(T_{i n}\right)$, coolant temperature $\left(T_{c}\right)$ and the equivalence ratio for a particular operating condition are displayed next to the incylinder pressure traces. The SOC, CO and UHC values are also shown next to the respective HRR curves for comparison between the no reformation and reformation fuelling case. The displayed UHC values are calculated as a percentage of the total fuel injected rather than ppm for a particular operating condition. It can be noticed that there is a rise in the HRR curve at $15^{\circ} \mathrm{CA} \mathrm{BTDC}$ at which point the reformation chamber is opened. The increase in the HRR value is due to the artifact of the HRR calculation where the opening is considered as a ramp with 5 CA duration for complete opening from 15 CA BTDC. The artifact could have been minimized if a longer duration was used in the calculation.
Dwie ciągłe linie (oznaczone na rys. 3 jako (a) i (b)) obrazują wykresy ciśnienia podczas otwarcia (a) i zamknięcia (b) komory reformingowej w ciągu całego cyklu.

Różnica między ich maksymalnymi wartościami wynika z różnicy objętości komory sprężania pomiędzy przypadkami (a) i (b). Objętość komory sprężania jest obniżona o 25\% dla przypadku (b), co skutkuje zwiększonym ogólnym stopniem sprężania silnika. Stopień sprężania silnika z komorą reformingową zamkniętą w ciągu suwu sprężania wynosi 21:1. Przerywana linia na rys. 3 przedstawia wykres ciśnienia w czasie otwarcia komory reformingowej przy kącie $15^{\circ} \mathrm{OWK}$ przed GMP i gdy jest zamknięta przy kącie $80^{\circ} \mathrm{OWK}$ po GMP (obecna konfiguracja). Należy zauważyć, że objętość komory sprężania w GMP przy tych warunkach pracy silnika (linia przerywana) jest równa przypadkowi (a) (warunki pracy silnika dla maksymalnej wartości ciśnienia 30 bar). Jednakże zmiana czasu otwarcia komory reformingowej podczas suwu sprężania prowadzi do chwilowego zmiennego stopnia sprężania silnika podczas środkowego okresu suwu sprężania. Zmiana stopnia sprężania podwyższa ciśnienie maksymalne i temperaturę na końcu sprężania (GMP), co pokazano na rys. $3 \mathrm{w}$ porównaniu do linii ciągłej (a). Na rysunku 3 przerywana linia najpierw podąża za krzywą ciśnienia z komorą zamkniętą (ciągła linia (b)) do kąta $15^{\circ} \mathrm{OWK}$ przed GMP, a następnie kieruje się w dół do krzywej ciśnienia, która przedstawia warunki otwartej komory (linia ciągła (a)) po przekroczeniu wartości kąta $10^{\circ}$ OWK po GMP. Prowadzi to do osiągnięcia wyższego ciśnienia i temperatury w GMP niż podczas sprężania w silniku konwencjonalnym, co stanowi zaletę proponowanej technologii reformingu. Zmieniając czas otwarcia komory reformingowej podczas sprężania, można zmieniać chwilę zapłonu dla konkretnego ładunku i temperatury chłodziwa. Tę zależność potwierdzają wyniki prezentowanych tu badań, gdzie spalanie miało miejsce tylko wtedy, gdy zawór jest otwarty powyżej wartości $15^{\circ} \mathrm{OWK}$ przed GMP dla wszystkich warunków pracy omówionych poniżej.

Rysunki od 4 do 9 przedstawiają ciśnienie wewnątrz cylindra i stężenie wodoru dla różnych warunków pracy silnika. Na wszystkich rysunkach ciągła linia oznacza brak reformingu, a przerywana linia ilustruje część paliwa wtryskiwanego do reformingu. Temperatura ładunku $\left(\mathrm{T}_{\mathrm{in}}\right)$, temperatura chłodziwa $\left(\mathrm{T}_{\mathrm{c}}\right)$ i współczynnik równoważności dla konkretnych warunków pracy silnika są zaprezentowane obok wykresów ciśnienia wewnątrz cylindra.

Dla porównania przypadków zasilania paliwem z reformingiem i bez niego przedstawiono chwilę zapłonu, stężenie tlenków węgla (CO) i niespalonych węglowodorów (UHC) obok odpowiednich krzywych przedstawiających stężenie wodoru. Zaprezentowane wartości niespalonych węglowodorów wyliczano w procentach całkowitej objętości wtryskiwanego paliwa, a nie w jednostkach ppm dla konkretnych warunków pracy silnika. Można zauważyć, że występuje wzrost krzywej stężenia wodoru przy kącie $15^{\circ} \mathrm{OWK}$ przed GMP, kiedy komora reformingu jest otwarta.

Zwiększenie szybkości wydzielania ciepła (HRR) jest spowodowane metodą obliczania stężenia wodoru, w której za otwarcie przyjmuje się przedział kąta $5^{\circ} \mathrm{OWK}$ do całko- 
However, the duration was chosen based on the in-cylinder pressure trace from motoring condition (Fig. 3), where the pressure has a negative $\mathrm{dP} / \mathrm{dCA}$ at $10 \mathrm{CABTDC}$ signifying the reformation chamber is open. This is confirmed by examining Figs. 4 through 9 where there is a similar rise in the HRR value at $15^{\circ} \mathrm{CA} \mathrm{BTDC}$ for the no reformation fuelling condition (solid line in Figs. 4 through 9).

In Figures 4 through 6 the intake charge temperature and the percentage fuelling ( $10 \%$ of total fuel per cycle) were kept constant and the only parameter varied was the fuel-air equivalence ratio. In general, comparing the no reformation fuelling case (solid line) in Figs. 4 through 6, it can be noticed that the SOC is advanced with increase in equivalence ratio for the same operating condition. Also, the $\mathrm{CO}$ and $\mathrm{UHC}$ level in the exhaust is also decreased with increase in the equivalence ratio. This trend with equivalence ratio was also seen in our earlier study where the influence of EGR and equivalence ratio on HCCI combustion was analyzed without in-cylinder fuel reformation, [14].

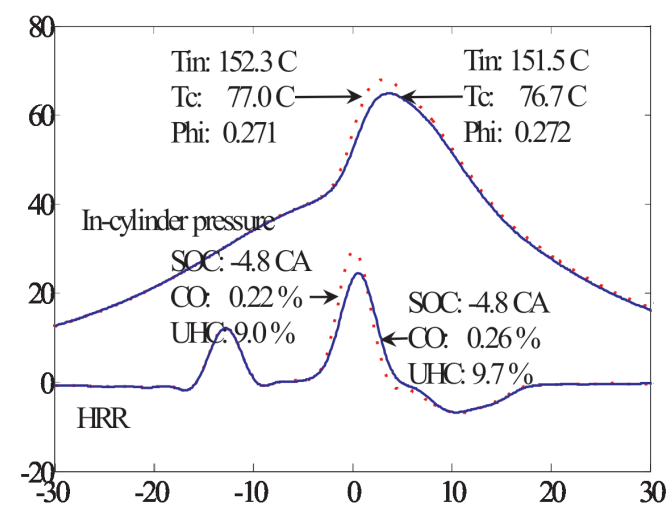

Fig. 4. In-cylinder pressure and HRR for $\phi=0.27,1120 \mathrm{rpm}$ and $10 \%$ fuel injected for reformation

Rys. 4. Ciśnienie wewnątrz cylindra i HRR dla $\phi=0,27,1120 \mathrm{obr} / \mathrm{min}$ i $10 \%$ paliwa wtryskiwanego do reformingu

From Fig. 4, for $\phi=0.27$, it can be noticed that with $10 \%$ reformation fuelling (dotted line) the $\mathrm{CO}$ and $\mathrm{UHC}$ levels is further reduced when compared to the no reformation fuelling case (solid line). Furthermore, the peak HRR value is higher and the HRR duration is shorter for the reformation case. This shows that the hydrogen-enriched reformation products help in attaining higher fuel conversion efficiency during the HCCI combustion of lean fuel-air mixture. The advantage of the in-cylinder reformation on HCCI combustion is also evident from the IMEP value (Fig. 10) obtained for the reformation fuelling case (2.38 bar) which is higher than the no reformation fuelling case (2.18 bar). Similar reduction in $\mathrm{UHC}$ and $\mathrm{CO}$ levels with higher $\mathrm{HR}$ values was seen in [13] with in-cylinder reformation using NVO. However, in Fig. 4 there was no significant change in the $\mathrm{SOC}$ between the reformation and the no reformation fuelling conditions.

An interesting trend emerges for the $10 \%$ reformation case when the equivalence ratio is changed. As the equivalence ratio is increased, the SOC is retarded and the decrease witego otwarcia od kąta $15^{\circ} \mathrm{OWK}$ przed GMP. Parametr ten mógłby być zminimalizowany, gdyby użyto dłuższego czasu trwania w obliczeniach. Jednak czas trwania wybrano na podstawie wykresu zależności ciśnienia wewnątrz cylindra od warunków pracy silnika (rys. 3), gdzie ciśnienie ma negatywny przyrost $\mathrm{dP} / \mathrm{d} \alpha$ przy kącie $10^{\circ} \mathrm{OWK}$ przed GMP, wskazując na otwarcie komory reformingu. Potwierdza to analiza rys. od 4 do 9 , gdzie występuje podobny wzrost wartości stężenia wodoru przy kącie $15^{\circ} \mathrm{OWK}$ przed GMP w warunkach niereformowania paliwa (linia ciągła na rys. od 4 do 9).

Na rysunkach od 4 do 6 temperatura ładunku i procent paliwa ( $10 \%$ całkowitej ilości paliwa na cykl) były stałe, a jedynym zmiennym parametrem był współczynnik równoważności paliwo-powietrze.

Ogólnie, porównując przypadek niereformowania paliwa (ciągła linia na rys. od 4 do 6), można zauważyć, że moment zapłonu zostaje przyspieszony wraz ze wzrostem współczynnika równoważności dla tych samych warunków pracy

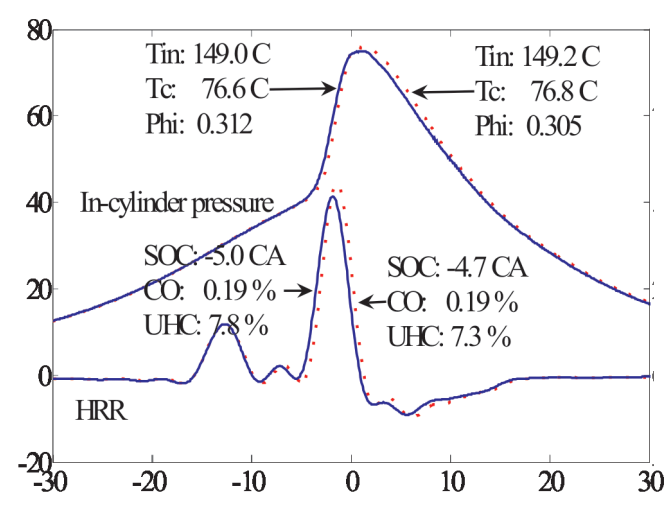

Fig. 5. In-cylinder pressure and HRR for $\phi=0.31,1120 \mathrm{rpm}$ condition and $10 \%$ fuel injected for reformation

Rys. 5. Ciśnienie wewnątrz cylindra i stężenie wodoru dla $\phi=0,31$, $1120 \mathrm{obr} / \mathrm{min}$ i $10 \%$ paliwa wtryskiwanego do reformingu

silnika. Poza tym poziom tlenków węgla i niespalonych węglowodorów UHC w spalinach zmniejsza się ze wzrostem współczynnika równoważności. Tę tendencję współczynnika równoważności można było również zauważyć we wcześniejszym badaniu, gdzie wpływ EGR i współczynnika równoważności na spalanie w silnikach HCCI analizowano bez reformingu paliwa wewnątrz cylindra [14].

$\mathrm{Z}$ rysunku 4 , dla $\phi=0,27$, można zauważyć, że przy $10 \%$ reformingu paliwa (przerywana linia), poziomy CO i UHC są bardziej zredukowane w porównaniu z niereformowanym paliwem (linia ciągła). Co więcej, maksymalna wartość wskaźnika stężenia wodoru jest wyższa i czas trwania zasilania wodorem jest krótszy przy reformingu. To pokazuje, że produkty reformingu o zwiększonej zawartości wodoru pomagają w osiąganiu wyższego współczynnika wykorzystania paliwa podczas spalania ubogiej mieszanki paliwo-powietrze w silnikach HCCI. Korzyści z reformingu wewnątrz cylindra dla spalania HCCI są wyraźnie widoczne w przypadku wartości średniego ciśnienia efektywnego (rys. 10) uzyskanego dla zasilania paliwem po reformingu $(2,38$ 
in $\mathrm{CO}$, UHC levels are diminished when compared to their corresponding no reformation fuelling case. The difference in the HRR peak value and the HRR duration is also reduced with an increase in the equivalence ratio for the reformation fuelling case. Specifically in Fig. 6 the reformation products act more like EGR by delaying SOC with no reduction in HRR duration, UHC and CO levels. The trend is also witnessed with the IMEP (Fig. 10), where the higher IMEP for

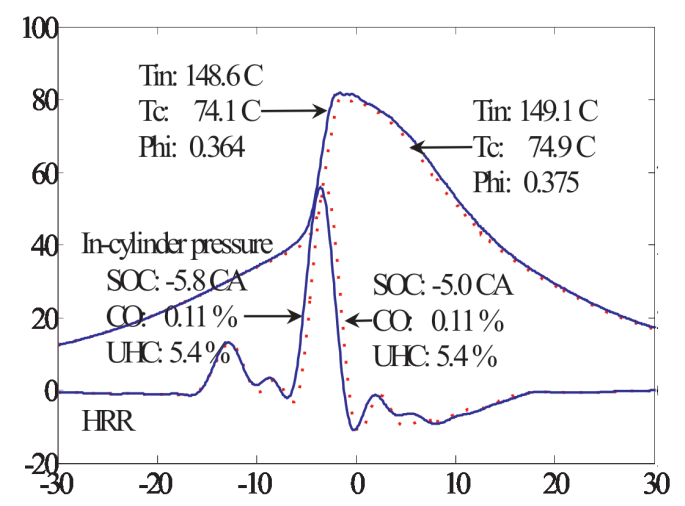

Fig. 6. In-cylinder pressure and HRR for $\phi=0.37,1120 \mathrm{rpm}$ and $10 \%$ fuel injected for reformation

Rys. 6. Ciśnienie wewnątrz cylindra i stężenia wodoru dla $\phi=0,37$, $1120 \mathrm{obr} / \mathrm{min}$ i $10 \%$ paliwa wtryskiwanego do reformingu

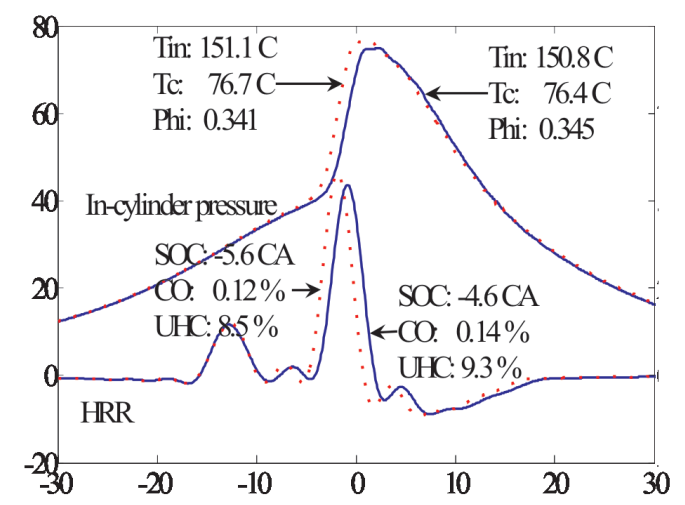

Fig. 8. In-cylinder pressure and HRR for $\phi=0.34,1080 \mathrm{rpm}$ and $20 \%$ fuel injected for reformation

Rys. 8. Ciśnienie wewnątrz cylindra i wskaźnik stężenia wodoru dla $\phi=0,34,1080 \mathrm{obr} / \mathrm{min}$ i $20 \%$ reformingu paliwa

the $10 \%$ in-cylinder reformation fuelling condition over their corresponding no reformation fuelling case diminished with increase in engine operating equivalence ratio. For Fig.5 with $\phi=0.31$, the corresponding IMEP (Fig. 10) for the 10\% reformation fuelling case is 2.59 bar, slightly higher than the no reformation condition (2.45 bar). Whereas, for the Fig. $6(\phi=0.37)$, the $10 \%$ reformation fuelling case showed a lower IMEP value of 2.68 bar (Fig. 10) when compared to the no reformation case (2.89 bar). It should be realized that the combustion products are trapped for reformation at $80^{\circ}$ CA ATDC during the expansion stroke in all runs and most of the equivalence ratios analyzed are lower than that of Eq. $1(\phi=0.37)$. Furthermore, the percentage reformation fuelling $(10 \%)$ is much less than the theoretical reformation bara), które jest wyższe niż przy zasilaniu paliwem bez reformingu (2,18 bara). Podobne zmniejszenie poziomu emisji niespalonych węglowodorów i CO wraz ze zwiększeniem stężenia wodoru było widoczna w [13] z reformingiem wewnątrz cylindra z użyciem strategii NVO. Jednakże na rys. 4 nie ma wyraźnej zmiany w momencie zapłonu pomiędzy zasilaniem paliwa po reformingu a zasilaniem bez reformingu.

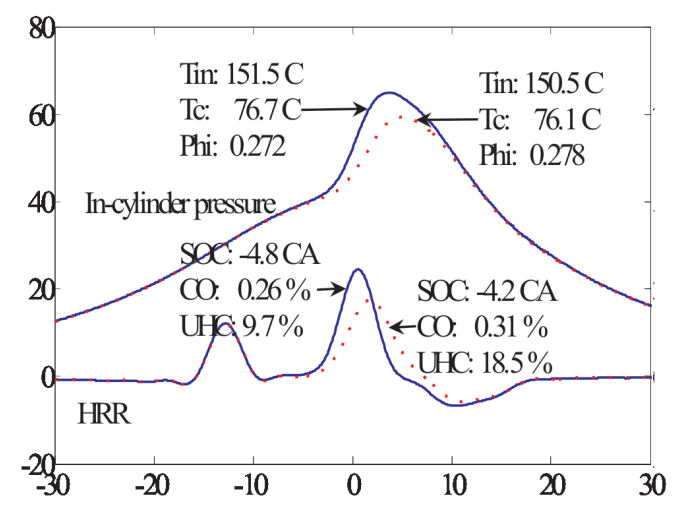

Fig. 7. In-cylinder pressure and HRR for $\phi=0.27,1120 \mathrm{rpm}$ and $25 \%$ fuel injected for reformation

Rys. 7. Ciśnienie wewnątrz cylindra i wskaźnik stężenia wodoru dla $\phi=0,27,1120 \mathrm{obr} / \mathrm{min}$ i $25 \%$ paliwa

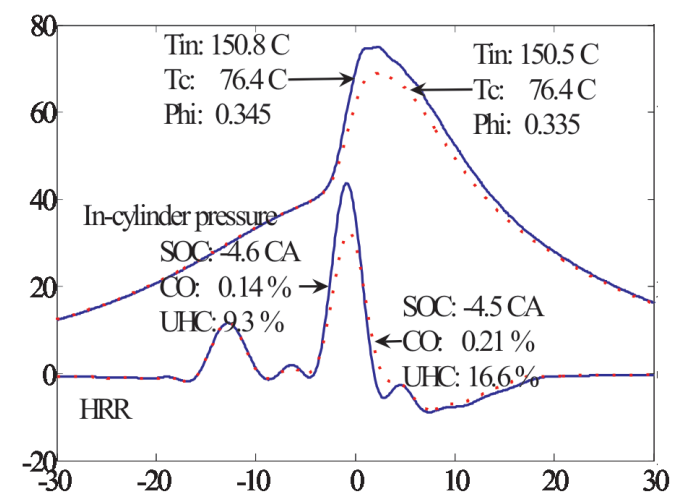

Fig. 9. In-cylinder pressure and HRR for $\phi=0.34,1080 \mathrm{rpm}$ and $25 \%$ fuel injected for reformation

Rys. 9. Ciśnienie wewnątrz cylindra i wskaźnik stężenia wodoru dla $\phi=0,34,1080 \mathrm{obr} / \mathrm{min}$ i 25\% reformingu wtryskiwanego paliwa

Ciekawa tendencja pojawia się dla przypadku z reformingiem na poziomie $10 \%$, kiedy zmienia się współczynnik równoważności.

Wraz ze wzrostem współczynnika równoważności, chwila samozapłonu jest opóźniona, a spadki emisji CO i niespalonych węglowodorów słabną, w porównaniu z odpowiadającym im przypadkiem zasilania paliwem bez reformingu. Różnica między maksymalną wartością wskaźnika stężenia wodoru i trwania wzrostu stężenia wodoru zmniejsza się wraz ze wzrostem współczynnika równoważności przy reformingu. W szczególności (rys. 6) produkty reformingu, podobnie jak system recyrkulacji spalin, opóźniają chwilę samozapłonu, nie skracają czasu wzrostu stężenia wodoru, ani nie zmniejszają poziomów emisji niespalonych węglo- 
level $(40.5 \%$ for $\phi=0.37)$, which was calculated based on only the oxygen content of the trapped combustion products. Hence, in theory, considering only the oxygen content, an engine operating at a lower equivalence ratio should favor the reformation reaction (Eq. 1) more towards complete combustion compared to the engine operating at higher equivalence ratios. However, the trend is reversed when comparing Figs 4 through 6 . This is mainly due to a lower temperature of the trapped combustion products which enter the reformation process for the engine operating at $\phi=0.27$ when compared to the higher equivalence ratios $(\phi=0.31$ and $\phi=0.37)$. For the $\phi$ $=0.27$ condition, even with higher oxygen content in the trapped combustion products, the lower temperature of the trapped combustion products leads to a favorable reformation condition and does not allow for complete conversion of percentage fuel injected to $\mathrm{CO}_{2}$ and $\mathrm{H}_{2} \mathrm{O}$. Whereas, with increase in equivalence ratio the temperature of the trapped combustion products increases and the fuel injected for reformation approaches complete combustion $\left(\mathrm{CO}_{2}\right.$ and $\left.\mathrm{H}_{2} \mathrm{O}\right)$ rather than reformation. This can be clearly seen with Fig. 6 where the reformation products acts more like EGR when compared to Fig. 4. This indicates that the temperature and the oxygen content play a critical role during the reformation period in either achieving hydrogen enriched reformate gas or complete combustion during the reformation period. In order to clarify this effect the percentage reformation fuelling is increased in Fig. 7 though 9.

Figure 7 shows the in-cylinder pressure and HRR comparison between the no reformation fuelling and $25 \%$ reformation fuelling case. The fuel-air equivalence ratio used for this condition is 0.27 , as in Fig. 4. Comparing Fig. 4 and 7 it can be noted that with an increase in the reformation fuelling percentage from $10 \%$ to $25 \%$, the SOC is retarded and the combustion efficiency also deteriorates (CO and UHC increases).

This is also seen in the IMEP trend (Fig. 10) where the $10 \%$ reformation fuelling case $(2.07$ bar $)$ falls below the no reformation fuelling condition (2.18 bar). Even though excess oxygen content of the trapped combustion products favors higher reformation fuelling percentage in the case of $\phi=0.27$, it should be realized that the temperature of the trapped combustion products is decreased with increase in the reformation fuelling percentage due to higher enthalpy of vaporization of ethanol. This in turn leads to a decrease in the overall temperature during the reformation process and does not favor the reformation reaction, which is evident during the subsequent HCCI combustion with the reformation products in Fig. 7. This phenomenon of existence of optimal reformation fuel percentage for a particular operating condition is further confirmed when looking into Figs. 8 and 9.

Figure 8 shows the in-cylinder pressure and HRR comparison between the no reformation fuelling condition and the $20 \%$ reformation fuelling condition. The fuel-air equivalence ratio for this condition is 0.34 which lies between the equivalence ratios in Figs. 5 and 6. As mentioned above, from Figs. 5 and 6, it was clear that the $10 \%$ reformation fuelling was not the optimal amount since the increase in trapped combustion products temperature (with increase in engine operating equivalence ratio) shifted the reformation wodorów i CO. Tendencję tę również widać w przypadku średniego ciśnienia efektywnego (rys. 10), gdzie wyższe ciśnienie przy $10 \%$ reformingu paliwa wewnątrz cylindra, w porównaniu do zasilania paliwem bez reformingu, malało ze wzrostem współczynnika równoważności silnika. $\mathrm{Na}$ rysunku 5, z $\phi=0,31$, analogiczny wskaźnik ciśnienia efektywnego (rys. 10) z reformingiem paliwa wynosi 2,59 bara, czyli jest nieznacznie wyższy niż bez reformingu paliwa $(2,45$ bara). Natomiast na rys. $6(\phi=0,37)$ przypadek zasilania paliwem z 10-procentowym reformingiem pokazał niższą wartość wskaźnika ciśnienia efektywnego 2,68 bara (rys. 10) w porównaniu do zasilania paliwem bez reformingu (2,89 bara). Należy zdać sobie sprawę z tego, iż produkty spalania są uwięzione $\mathrm{w}$ procesie reformingu przy kącie $80^{\circ}$ OWK po GMP we wszystkich cyklach pracy silnika i że większość analizowanych współczynników równoważności jest niższych niż ten $\mathrm{z}$ równania $(1)-(\phi=0,37)$. Ponadto procent paliwa poddanego reformingowi $(10 \%)$ jest dużo mniejszy niż jego teoretyczny poziom $(40,5 \%$ dla $\phi=0,37)$, który obliczono jedynie w oparciu o zawartość tlenu w uwięzionych produktach spalania. Stąd teoretycznie, biorąc pod uwagę jedynie zawartość tlenu, praca silnika przy niższym współczynniku równoważności powinna sprzyjać reakcji reformingu (równanie (1)), prowadząc do całkowitego spalania w porównaniu z silnikiem pracującym przy wyższych współczynnikach równoważności. Jednak ta tendencja jest odwrócona, gdy porównamy rys. od 4 do 6 . Jest to spowodowane głównie niższą temperaturą uwięzionych produktów spalania, które uczestniczą w procesie reformingu dla silników pracujących przy $\phi=0,27 \mathrm{w}$ porównaniu z wyższymi współczynnikami równoważności $(\phi=0,31, \phi==0,37)$. Gdy $\phi=0,27$, produkty spalania uczestniczące w procesie reformingu mają niższą temperaturę od produktów spalania przy większych wartościach $\phi$. Tworzy to sprzyjające warunki reformingu i uniemożliwia przekształcenie dawki paliwa poddanej reformingowi do $\mathrm{CO}_{2} \mathrm{i}_{2} \mathrm{O}$. Natomiast wraz ze wzrostem współczynnika równoważności, temperatura uwięzionych produktów spalania rośnie i wtryskiwane paliwo do reformingu ulega prawie całkowitemu spalaniu $\left(\mathrm{CO}_{2}\right.$ i $\left.\mathrm{H}_{2} \mathrm{O}\right)$. Wyraźnie to widać na rys. 6 , gdzie produkty reformingu przynoszą efekty podobne do efektów działania systemu recyrkulacji spalin w porównaniu z rys. 4. To sugeruje, że temperatura i zawartość tlenu odgrywają kluczową rolę w procesie reformingu, prowadząc albo do uzyskania gazu o zwiększonej zawartości wodoru, albo do całkowitego spalania. W celu wyjaśnienia tego efektu zwiększono procent paliwa poddawanego reformingowi (rys. od 7 do 9).

Rysunek 7 przedstawia ciśnienie wewnątrz cylindra wraz z porównaniem wskaźnika stężenia wodoru pomiędzy paliwem bez reformingu i paliwem z 25-procentowym reformingiem. Współczynnik równoważności paliwo-powietrze użyty w tym przypadku wynosi 0,27 , jak na rys. 4. Porównując rys. od 4 do 7 , można zauważyć, że wraz ze wzrostem procentu reformingu paliwa od 10 do $25 \%$ chwila samozapłonu jest opóźniona, a sprawność spalania się pogarsza (poziomy CO i niespalonych węglowodorów wzrastają). 
reactions towards complete combustion. From Fig. 8 it can be seen that the increase in the reformation fuelling percentage $(20 \%)$ with higher equivalence ratio $(\phi=0.34)$ favors the reformation process and has a positive impact on the subsequent regular HCCI combustion process. The IMEP for the $20 \%$ reformation fuelling condition (Fig. 10) was 2.6 bar compared to 2.53 bar for the no reformation fuelling condition. The $20 \%$ reformation fuelling condition advances SOC and decreases the $\mathrm{CO}$ and UHC levels when compared to the no reformation case. However, with further increase in the percentage reformation fuelling to $25 \%$ (Fig. 9) the SOC is retarded and the combustion efficiency deteriorates (CO and UHC increases). This is also evident from the IMEP where the $25 \%$ reformation fuelling condition (Fig. 10) drops to 2.27 bar when compared to the no reformation fuelling condition ( 2.53 bar). This shows that for the 0.34 equivalence ratio the optimal reformation fuelling percentage that has a desired impact on the HCCI combustion is $20 \%$.

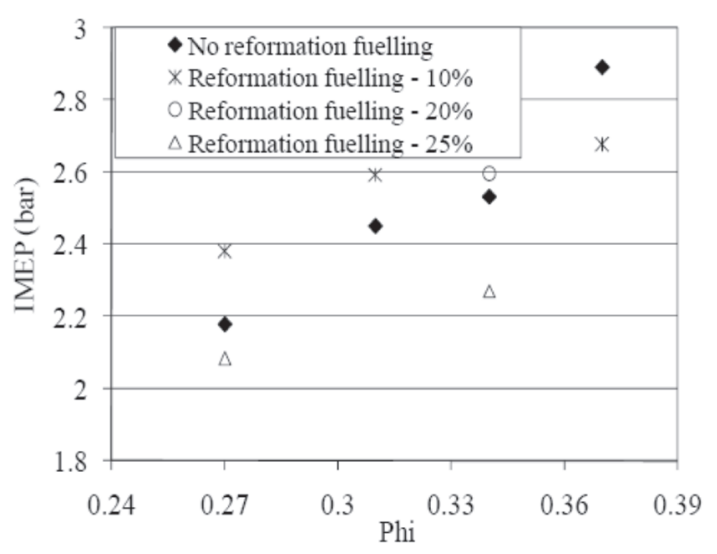

Fig. 10. IMEP vs equivalence ratio for various reformation fuelling percentage

Rys. 10. Zależność wskaźnika średniego ciśnienia efektywnego od wspótczynnika równoważności dla różnego procentu reformingu paliwa

Figure 11 shows the $\mathrm{COV}_{\text {IMEP }}$ values for the different tested reformation fuelling and no reformation fuelling conditions. It can be seen from Fig. 11 that all the reformation fuelling condition except one ( 0.27 equivalence ratio and $25 \%$ reformation fuelling condition) showed lower $\mathrm{COV}_{\text {IMEP }}$ values compared to their respective no reformation fuelling condition. However, it should be realized that IMEP values for the $\phi=0.37$ with $10 \%$ reformation fuelling condition and $\phi=0.34$ with $25 \%$ reformation fuelling where lower compared to their respective no reformation fuelling conditions. This shows that even at operating conditions where the reformation fuelling percentage is not at its optimized value, the products of fuel reformation helps in attaining a lower $\mathrm{COV}_{\text {IMEP }}$ values compared to their respective no reformation fuelling conditions.

It should be said here that the $\mathrm{CO}$ and UHC levels for all the above experimental runs were high and would require exhaust after-treatment. Similar higher levels of CO and UHC were also reported for lean HCCI combustion of fuelair mixtures [15].
Widać to również w tendencji zmian średniego ciśnienia efektywnego (rys. 10), gdzie dla 10\% reformingu paliwa $(2,07$ bar) spada ono poniżej wartości dla paliwa bez reformingu (2,18 bara). Mimo że nadmierna zawartość tlenu uwięzionych produktów spalania sprzyja wyższemu procentowi reformingu paliwa dla $\phi=0,27$, należy zauważyć, że temperatura uwięzionych produktów spalania spada ze wzrostem procentu reformingu paliwa $\mathrm{z}$ powodu wyższej entalpii parowania etanolu. To z kolei prowadzi do spadku temperatury całkowitej procesu reformingu i nie sprzyja reformingowi, co jest widoczne podczas kolejnego spalania produktów reformingu w silnikach HCCI (rys. 7). Zjawisko istnienia optymalnego procentu reformingu paliwa dla konkretnych warunków pracy silnika potwierdzają rysunki od 8 do 9 .

Ciśnienie wewnątrz cylindra i porównanie wskaźnika stężenia wodoru między paliwem bez reformingu i paliwem z 20-procentowym reformingiem przedstawiono na rys. 8. Współczynnik nadmiaru powietrza użyty dla tego

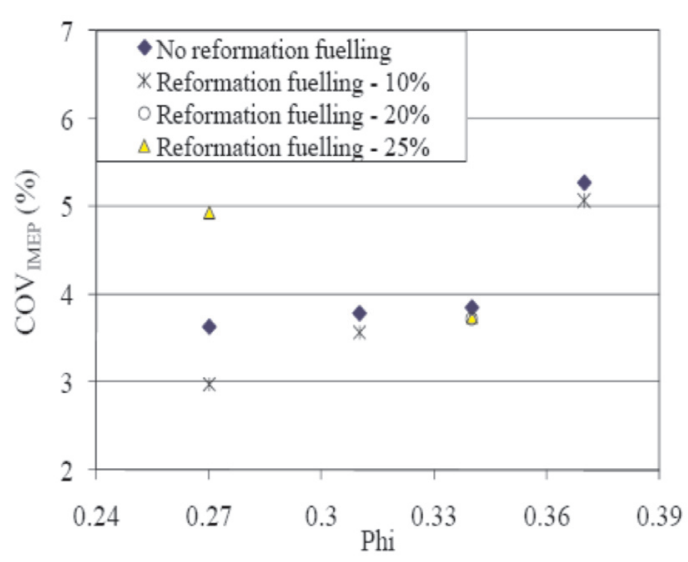

Fig. 11. $\mathrm{COV}_{\mathrm{IMEP}}$ vs equivalence ratio for various reformation fuelling percentage

Rys. 11. Zależność COV $V_{\text {IMEP }}$ od współczynnika równoważności dla różnego procentu paliwa reformingu

przypadku wynosi 0,34, co zawiera się pomiędzy współczynnikami równoważności przedstawionymi na rys. 5 i 6. Jak wspomniano wyżej, z rys. 5 i 6 wynika, że 10\% paliwa z reformingu nie było optymalną ilością, ponieważ wzrost temperatury uwięzionych produktów spalania (ze wzrostem działającego współczynnika równoważności silnika) przesunął reakcje reformingu w kierunku całkowitego spalania. Wzrost procentu paliwa reformingu (20\%) przy wyższym współczynniku równoważności $(\phi=0,34)$ sprzyja procesowi reformingu i ma pozytywny wpływ na kolejny regularny proces spalania HCCI (rys. 8). Średnie ciśnienie użyteczne dla 20\% reformingu paliwa (rys. 10) wynosiło 2,6 bar w porównaniu z 2,53 bar dla paliwa konwencjonalnego. W stosowaniu $20 \%$ reformingu paliwa przyspiesza się moment zapłonu i obniża poziomy $\mathrm{CO}$ i $\mathrm{HC}$ w porównaniu do przypadku bez reformingu. Jednak z dalszym wzrostem reformingu do $25 \%$ (rys. 9), moment zapłonu jest opóźniony, a sprawność spalania się pogarsza (CO i HC wzrastają). Widać to również z wartości średniego ciśnienia użytecznego, gdzie $25 \%$ reformingu paliwa (rys. 10) zmniejsza jego wartość do 


\section{Conclusions}

In this paper, a new in-cylinder reformation strategy to control the on-set of HCCI combustion has been proposed and tested in an experimental HCCI engine fuelled with lean ethanol/air mixtures. The methodology adopted here does not affect the volumetric efficiency of the engine as in the case of NVO technology and provides control over the mixing of the reformation products with fresh charge when compared with other processes. Furthermore, employing the proposed methodology excluding the benefits from reformation process shows prospects of controlling the HCCI combustion on-set (SOC) simply by manipulating the reformation chamber opening time during the compression stroke. The experimental results from the proto-type reformation chamber demonstrate that the products from in-cylinder reformation are effective in controlling the HCCI combustion on-set (SOC) and reduce the regulated engine-out emissions. The experimental results also indicate that there is an optimal in-cylinder reformation fuelling percentage for each operating condition that has a desired impact on the regular HCCI combustion process.

\section{Acknowledgements}

The financial support of the AUTO21, Imperial Oil and University of Windsor School of Graduate Studies is gratefully acknowledged.

Paper reviewed

\section{Bibliography/Literatura}

[1] Zhang Y., He B., Xie H., Zhao H.: SAE Paper 2006-01-0631 (2006).

[2] Christensen M., Johansson B.: SAE Paper 2000-01-1835 (2000).

[3] Zhao F., Asmus T., Assanis D., Dec J., Eng J., Najt P. (eds.): Homogenous Charge Compression Ignition (HCCI) Engines; Key Research and Development Issues, SAE International, Warrendale P.A., 2003.

[4] Christensen M., Hultqvist A., Johansson B.: SAE Paper 199901-3679 (1999).

[5] Christensen M., Johansson B.: SAE Paper 982454 (1998).

[6] Cairns A., Baxill H.R.: SAE Paper 2005-01-0133 (2005).

[7] Christensen M., Johansson B., Amneus P., Mauss F. : SAE Paper 980787 (1998).

[8] Urata Y., Awasaka M., Takanashi J., Kakinuma T., Hakozaki T., Umemoto A.: SAE Paper 2004-01-1898 (2004).

[9] Kook S., Bae C.: SAE Paper 2004-01-0938 (2004).

[10] Urushihara T., Hirava K., Kakuhou A., Itoh T.: SAE Paper 2003-01-0749 (2003)

[11] Koopmans L., Ogink R., Denbratt I.: SAE Paper 2003-011854 (2003).

[12] Guohong T., Wang J., Shuai S., Wang Z., An X.: SAE Paper 2006-01-0415 (2006).

[13] Waldman J., D. Nitz, T. Aroonsrisopon, D. Foster, M. Iida, SAE Paper 2007-01-0219 (2007).

[14] G. Gnanam, Haggith D., Sobiesiak A., Reader G.: Proc. International Congress of Combustion Engines, PTNSS 2007-SC2 (2007), p. 311-321.

[15] Van Blarigan P., Paradiso N., Goldsborough S.: SAE Paper 982484 (1998).
2,27 bar w porównaniu do paliwa bez reformingu (2,53 bar). To pokazuje, że dla współczynnika równoważności 0,34 optymalny procent paliwa reformingu, który ma pożądany wpływ na spalanie HCCI, to $20 \%$.

Rysunek 11 przedstawia wartości $\mathrm{COV}_{\text {IMEP }}$ dla różnych testowanych paliw reformingu i warunków konwencjonalnych. Pokazuje on, że wszystkie warunki paliwa reformingu, oprócz jednego (współczynnik składu mieszanki 0,27 i 25\% reforming paliwa), wykazały niższe wartości $\mathrm{COV}_{\text {IMEP }}$ w porównaniu do przypadku bez reformingu. Jednak należy zdać sobie sprawę, że wartości średniego ciśnienia użytecznego dla $\phi=0,37$ i $10 \%$ reformingu paliwa oraz dla $\phi=0,34$ i $25 \%$ reformingu paliwa były niższe w porównaniu do warunków bez reformowania paliwa. To pokazuje, że nawet wówczas, gdy procent paliwa reformingu nie ma zoptymalizowanej wartości, produkty reformingu paliwa pomagają w osiąganiu niższych wartości $\mathrm{COV}_{\text {IMEP }}$ w porównaniu do przypadku bez reformowania paliwa. Należy tutaj odnotować, że poziomy CO i HC dla wszystkich powyższych cykli eksperymentalnych były wysokie i wymagały oczyszczania spalin. Podobne wysokie poziomy CO i HC odnotowano także dla spalania HCCI ubogich mieszanek paliwo-powietrze [15].

\section{Wnioski}

W artykule zaproponowano nową metodę kontroli chwili zapłonu w technologii HCCI, która jest oparta na procesie reformingu wewnątrz cylindra i przetestowano ją w eksperymentalnym silniku HCCI napędzanym ubogimi mieszankami etanol/powietrze. Zastosowana tutaj technologia nie ma wpływu na sprawność napełniania silnika, jak to ma miejsce w strategii NVO, i pozwala kontrolować mieszanie produktów reformingu ze świeżym ładunkiem w porównaniu $\mathrm{z}$ innymi procesami. Co więcej, zastosowanie proponowanej technologii, wyłączając korzyści procesu reformingu, ukazuje perspektywy kontrolowania chwili samozapłonu w spalaniu HCCI przez różnicowanie czasu otwierania komory reformingu podczas suwu sprężania. Wyniki eksperymentu z prototypowej komory reformingu dowodzą, że produkty $\mathrm{z}$ reformingu wewnątrz cylindra są efektywne w kontroli chwili samozapłonu HCCI i zmniejszają emisję z silnika. Wyniki badania wskazują także, że istnieje optymalny procent paliwa poddawanego reformingowi wewnątrz cylindra dla każdego warunku działania, który ma pożądany wpływ na regularny proces spalania HCCI.

\section{Podziękowania}

Szczególne podziękowania za wsparcie finansowe należą się AUTO21, Imperial Oil i Instytutowi Studiów Podyplomowych Uniwersytetu Windsor.

Mr. Andrzej Sobiesiak, PhD, - Professor and Head, Department of Mechanical, Automotive and Materials Engineering, University of Windsor, Canada.

Dr inż. Andrzej Sobiesiak - profesor i kierownik Wydziału Inżynierii Mechanicznej, Samochodowej i Materiałowej, Uniwersytetu Windsor, Kanada.

e-mail: asobies@uwindsor.ca 